\title{
Radioprotection in Dentistry: knowledge and practices
}

\author{
Radioproteção na Odontologia: conhecimento e práticas \\ Protección Radiológica en Odontología: conocimientos y prácticas
}

Received: 10/28/2021 | Reviewed: 11/08/2021 | Accept: 11/10/2021| Published: 11/13/2021

\author{
Thalía Tessaro Torresan \\ ORCID: https://orcid.org/0000-0002-4270-348X \\ Federal University of Rio Grande do Sul, Brazil \\ E-mail: thalia.tessaro@gmail.com \\ Isandra Caroline Rodrigues \\ ORCID: https://orcid.org/0000-0002-3272-8202 \\ University of Caxias do Sul, Brazil \\ E-mail: isandracrodrigues@gmail.com \\ Marina Caldas Poletto \\ ORCID: https://orcid.org/0000-0003-3715-628X \\ University of Caxias do Sul, Brazil \\ E-mail: Mcpoletto@ucs.br \\ Deise Renata Bringmann \\ ORCID: https://orcid.org/0000-0002-2849-225X \\ University of Caxias do Sul, Brazil \\ E-mail:deise.renata@ucs.br \\ Isadora Luana Flores \\ ORCID: https://orcid.org/0000-0002-6628-2122 \\ Federal University of Rio Grande do Sul, Brazil \\ E-mail:isadoraluanaflores@gmail.com \\ Thiago de Oliveira Gamba \\ ORCID: https://orcid.org/0000-0002-3941-9672 \\ University of Caxias do Sul, Brazil \\ E-mail: thiagodeo.gamba@gmail.com
}

\begin{abstract}
The present study aimed to identify the knowledge and attitudes of dental surgeons regarding the guidelines contained in Ordinance SVS/MS No. 453, dated June 1, 1998, in force until the year 2019 and later replaced with Collegiate Board Resolution (RDC) No. 330/19. Our objective was to identify the practices of professionals working in the dental field regarding the knowledge of the essential criteria for performing periapical, interproximal, panoramic, cephalometric or even cone beam computed tomography imaging exams. The research tool was a questionnaire consisting of 45 questions based on Administrative Rule 453/98, which addresses the requirements for the organization and operation of diagnostic radiology services. The questionnaire was sent to 150 dentists via institutional e-mail, and only 55 professionals returned it. The responses revealed that $64 \%$ of the dentists declared not to be aware of the guidelines of ordinance $453 / 98$ and $49.1 \%$ did not know the basic principles of radioprotection. Regarding the norms related to the environment, including the use of a chronometer, thermometer and timetemperature table, the study revealed that $83.6 \%$ of the interviewees did not use such equipment and that $74.5 \%$ of them were not aware of the technical details ofthe equipment. Regarding radiographic films, $64.5 \%$ answered that they did not know their sensitivity, and 25.5\% did not use them as a protective barrier during the exams. Finally, the study revealed that the professional practices adopted by dental surgeons are insufficient to meet the principle contained in ordinance 453/98 and in the RDC 330/19, regarding the exposure of patients to a radiation dose.
\end{abstract}

Keywords: Radioprotection; Dentists; Practice management, dental; Public health; Ionizing radiation.

\section{Resumo}

O presente estudo teve como objetivo identificar os conhecimentos e atitudes dos cirurgiões-dentistas em relação às diretrizes contidas na Portaria SVS/MS n ${ }^{\circ} 453$, de 1 de junho de 1998 vigente até o ano de 2019, posteriormente substituída pela Resolução da Diretoria Colegiada $n^{\circ} 330 / 19$. Essa abordagem visou identificar as práticas dos profissionais que trabalham na área odontológica, no que diz respeito ao conhecimento dos critérios essenciais para a realização de exames de imagem periapicais, interproximais, panorâmicos, cefalométricas ou mesmo tomografia computadorizada de feixe cônico. O método de pesquisa contou com a utilização de um questionário composto por 45 perguntas elaboradas com base na portaria 453/98, que aborda os requisitos para a organização e operação de serviços de radiologia diagnóstica, o qual foi enviado aos participantes 150 cirurgiões-dentistas via e-mail institucional, tendo obtido retorno apenas de 55 questionários. Dentre as respostas, $64 \%$ dos cirurgiões-dentistas declararam não ter conhecimento das diretrizes da portaria 453/98; 49,1\% não conheciam os princípios básicos da radioproteção. Já 
quanto às normas relativas ao meio ambiente, incluindo uso de cronômetro, de termômetro e tabela de tempotemperatura, o estudo evidenciou que $83,6 \%$ dos entrevistados não utilizam tais equipamentos, assim como 74,5\% desses não souberam informar detalhes técnicos acerca dos equipamentos. Relativo aos filmes radiográficos, 64,5\% respondeu desconhecer a sensibilidade desses, bem como $25,5 \%$ não os utilizam como barreira de proteção durante os exames. Por fim, o estudo revelou que as práticas profissionais adotadas pelos cirurgiões-dentistas são insuficientes para atender ao princípio que que constava na portaria 453/98 e que constam na RDC 330/19, quanto a exposição dos pacientes à dose de radiação.

Palavras-chave: Radioproteção; Dentistas; Gerenciamento de prática odontológica; Saúde pública; Radiação ionizante.

\section{Resumen}

El presente estudio tuvo como objetivo identificar los conocimientos y las actitudes de los cirujanos dentistas en relación con las directrices contenidas en la Ordenanza SVS/MS nº 453 del 1 de junio de 1998 en vigor hasta el año 2019, posteriormente sustituida por la Resolución del Consejo Colegiado no 330/19. Este enfoque tenía como objetivo identificar las prácticas de los profesionales que trabajan en el ámbito odontológico, en relación con el conocimiento de los criterios esenciales para la realización de exámenes de imagen periapical, interproximal, panorámica, cefalométrica o incluso de tomografía computarizada de haz cónico. El método de investigación empleó un cuestionario compuesto por 45 preguntas basadas en la Norma Administrativa 453/98, que aborda los requisitos para la organización y el funcionamiento de los servicios de radiodiagnóstico, que se envió a 150 dentistas por correo electrónico institucional, y sólo se devolvieron 55 cuestionarios. Entre las respuestas, el 64\% de los dentistas declaró no conocer las directrices de la ordenanza 453/98; el 49,1\% no conocía los principios básicos de la radioprotección. En cuanto a las normas relacionadas con el medio ambiente, incluyendo el uso de cronómetro, termómetro y tabla de tiempo-temperatura, el estudio evidenció que el 83,6\% de los encuestados no utilizan dichos equipos, así como que el $74,5 \%$ fueron incapaces de informar sobre los detalles técnicos de los mismos. En cuanto a las películas radiográficas, el 64,5\% contestó que no conocía su sensibilidad, así como el 25,5\% no las utilizaba como barrera de protección durante los exámenes. Por último, el estudio revela que las prácticas profesionales adoptadas por los cirujanosdentistas son insuficientes para cumplir con el principio que establece la ley 453/98 y que establece el RDC 330/19, en cuanto a la exposición de los pacientes a la dosis de radiación.

Palabras clave: Radioprotección; Dentistas; Gestión de prácticas, odontología; Salud pública; Radiación ionizante.

\section{Introduction}

Since the discovery of X-rays in 1895 , clinical conduct has changed from the "cut and see" era to the "see and cut" era, with radiographic examination gaining fundamental importance for the diagnosis, planning and follow-up of cases. Among all health professionals, dentists are those who use imaging examinations the most (Ihle et al., 2019; Shahab et al., 2012). However, although imaging examinations, whether periapical, interproximal, panoramic, cephalometric or even cone beam computed tomography, require low dose exposure, each exposure involves potential harm to the body due to its ability to induce biological effects, which fall into two categories, i.e., deterministic and stochastic. Deterministic effects result from a high dose exceeding a certain limit, i.e., the severity of the effect is proportional to the dose. Stochastic effects, on the other hand, are those due to exposure to any dose of radiation, with an all-or-nothing phenomenon of radiation-induced cancer occurring or not (Tsapaki, 2017; Chauhan \& Wilkins, 2019).

In view of this, no radiation exposure can be considered risk-free, a fact that significantly increases the concern about the possibble development of a carcinogen. Even if the risk of occurrence of a primary cancer resulting from exposure during conventional dental radiography is considered negligible, the risks related to cumulative doses should not be underestimated. Therefore, the use of radiation by the dentist comes with the responsibility to ensure adequate protection, exposing the patient to the lowest possible radiation dose (Binnal, 2013; An SY, 2018).

Any action that reduces radiation exposure is considered to be radioprotective according to e Ordinance SVS/MS 45398 (Brazil, 1998) and the resolution of ANVISA/RE1016 06 (Brazil,1998), which were repealed by Resolution RDC No. 330 of December 20, 2019 (Brazil, 2019). It should be noted that both aimed at the optimization of radiological protection and individual dose limitation. Such guidelines aim to expose the patient to the lowest possible radiation dose, considerably reducing the action of potential biological effects on the body. New devices and advanced methods have allowed lower patient 
exposures while still providing quality images. However, professionals still overexpose patients, without properly complying with radioprotection guidelines and therefore disregarding the the possible effects of ionization on the individual's health (Shahab et al., 2012; Chaudhry et al., 2016; Villalobos, Martorano, Juhás, \& Nakao, 2021).

In this respect, this subject has not been treated with the care it deserves, while it is of the utmost importance for the dental surgeon to know in advance the possible effects of ionization on the individual's health. Thus, when indicating imaging exams, the radioprotective measures mentioned in the RDC $\mathrm{n}^{\circ} 330$ should be followed in order to expose the patient to the lowest possible dose of radiation, provided that the acquired image will permit to reach a diagnosis. It is essential that professionals avoid unnecessary radiation exposure in accordance with the fundamental principles of justification, optimization and limitation of radiological protection (Ihle et al., 2019; Binnal, 2013; Furmaniak et al., 2016).

On this basis, the objective of the present study was to analyze the actual knowledge of dental professionals in Caxias do Sul, a municipality in southern Brazil, regarding radioprotective methods in clinical settings and to identify the protocols used in order to determine the knowledge of dental surgeons regarding radiological protection at the time of examinations according to ANVISA ordinance 453/98, which was a regulatory document for health professionals until the year 2019, when it was replaced with RDC 330/19 (Brazil, 2019).

\section{Methodology}

This research is a retrospective exploratory cross-sectional study conducted on dentists by the application of an online questionnaire that aimed to investigate their knowledge and practice of the guidelines of ANVISA Ordinance 453/98. Which deals with mandatory radiation safety methods for health professionals, addressing issues about the environment, equipment, work procedures and quality control.

After approval by the Research Ethics Committee of Universidade de Caxias do Sul (UCS) under number CAAE: 26465819.8.0000. 5341, the questionnaires were sent by email using the Google Forms survey management application. All study material and the identity of the participants were kept confidential by the researchers. The data obtained were then tabulated and analyzed.

The questionnaire was prepared by the researchers based on the study of Ihle et al (2019) and ANVISA Ordinance 453/98 and contained 45 questions divided into 2 sections. The 39 questions of the first section covered 5 main domains, namely: (a) general information about the participant, (b) basic knowledge, (c) environment, (d) equipment, (e) work procedures, and (d) quality control. The second section contained 6 questions about the number of imaging exams required to achieve the maximum radiation dose for the public (patients). The inclusion criterion was based on dental offices and clinics located in the city of Caxias do Sul that perform imaging exams, whether periapical, interproximal, panoramic, cephalometric radiographs, as well as the advanced imaging exam called cone beam computed tomography.

Professionals (dental surgeons) not trained in Brazil were excluded from the study. Regarding general information, of the 55 participants, $63.6 \%$ were women and $36.4 \%$ were men, with a mean age of 34 years. Most $(45.5 \%)$ of the interviewees had $<5$ years of experience in dental practice, followed by $29.1 \%$ with $15-25$ years, $10.9 \%$ with $5-10$ years, $7.3 \%$ with 10-15 years, and 7.3\% with more than 25 years of experience. Most professionals had a specialization degree (69.1\%), with only $11(20 \%)$ having only a bachelor's degree, and 10.9\% having a master's degree. All professionalsl answered that they had access to X-ray equipment in the workplace. A total of 55 questionnaires out of the 150 sent were returned, corresponding to a response rate of $36.6 \%$. The results obtained were tabulated and analyzed using the SPSS statistical software. 


\section{Results and Discussion}

Protective equipment such as a lead apron, goggles, gloves, a thyroid shield and screen ensure the safety and health of professionals and patients (Okuno, 2018). A dosimeter is used to measure the radiation to which the professional is exposed and should be worn on the outside of the apron at chest height and should be read monthly to ensure safety (Herring, 2016). The most important organ for protection in dental radiology was the thyroid according to $90.9 \%$, bone marrow according to $5.5 \%$, skin according to $1.8 \%$, and sexual gonads according to $1.8 \%$. The technique involving the greatest dose of radiation to which the patient is exposed was the whole mouth periapical exam, reported by $70.9 \%$ of the respondents, followed by panoramic examination, reported by $29.1 \%$. Although $92.7 \%$ of the participants mentioned that they had received some theoretical and/or practical training in radioprotection during graduation,72.7\% reported the need to improve their knowledge about radioprotection to be implemented in their clinical practice.

Therefore, the basic radiographic knowledge and the attitudes adopted by the professionals may strongly influence the image results. Thus, quality assurance of radiographic images, equipment and related procedures is needed to avoid wrong or inconclusive diagnoses which may lead the health professional to request a new exposure of the patient, producing unnecessary doses and increased costs, besides the wear and tear of the equipment (MS, 2019; Mota et al., 2020). The first section of Table 1 a figure 1 lists the results regarding the issues related to the work environment obtained in the present study. The presence of adequate signage was mentioned by $89.1 \%$ of the professionals, while $83.6 \%$ of the respondents, when asked about the presence of an immersion thermometer, chronometer and time-temperature table to be used during radiographic processing, answered that they did not use them or did not have access to them.

Figure 1. Basic knowledge.

\section{Do you know the norms of Resolution 453/98?}

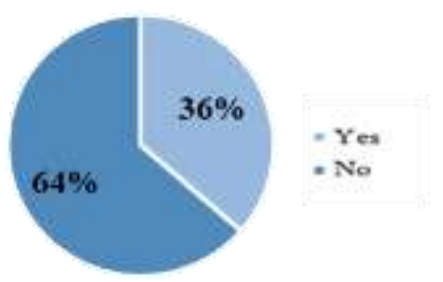

\section{Do you know the basics of radioprotection?}

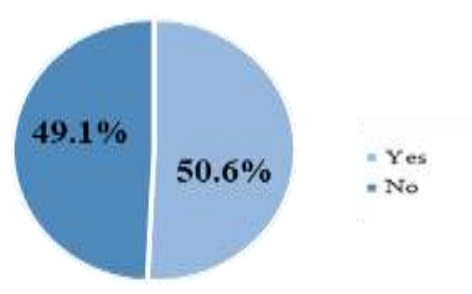

Source: Prepared by the authors (2019). 
Table 1. Environment, equipment and quality control.

\begin{tabular}{|c|c|}
\hline Questions & Answers \\
\hline \multicolumn{2}{|l|}{ ENVIRONMENT } \\
\hline \multicolumn{2}{|c|}{$\begin{array}{l}\text { Is there adequate signage (radiation warning on the access doors and radiological protection guidelines } \\
\text { board - as stated in Ordinance } 453 \text { ) in the environment where your } x \text {-ray equipment is located? }\end{array}$} \\
\hline Yes & $49(89.1 \%)$ \\
\hline No & $6(10.9 \%)$ \\
\hline \multicolumn{2}{|c|}{$\begin{array}{l}\text { If the process is manual, do you use an immersion thermometer, stopwatch and a time-temperature } \\
\text { chart when processing your film? }\end{array}$} \\
\hline Yes & $9(16.4 \%)$ \\
\hline No & $46(83.6 \%)$ \\
\hline \multicolumn{2}{|c|}{ EQUIPMENT } \\
\hline \multicolumn{2}{|c|}{ What is the tube voltage of your intraoral radiography equipment $(\mathrm{kVp})$ ? } \\
\hline$<50$ & $1(1.8 \%)$ \\
\hline $50-60$ & $1(1.8 \%)$ \\
\hline $60-70$ & $9(16.4 \%)$ \\
\hline$>70$ & $3(5.5 \%)$ \\
\hline I don't now & $41(74.5 \%)$ \\
\hline \multicolumn{2}{|l|}{ What type of collimator is used? } \\
\hline Circular & $51(92.7 \%)$ \\
\hline Rectangular & $0(0 \%)$ \\
\hline I don't know & $4(7.3 \%)$ \\
\hline \multicolumn{2}{|c|}{ Is your equipment's trigger cord at least 2 meters long? } \\
\hline Yes & $49(89.1 \%)$ \\
\hline No & $2(3.6 \%)$ \\
\hline I don't know & $4(7.3 \%)$ \\
\hline \multicolumn{2}{|l|}{ QUALITY CONTROL } \\
\hline \multicolumn{2}{|l|}{ How old is your X-ray equipment? } \\
\hline$\leq 1$ & $2(3.6 \%)$ \\
\hline$<5$ & $17(30.9 \%)$ \\
\hline 5-10 & $10(18.2 \%)$ \\
\hline$>10$ & $15(27.3 \%)$ \\
\hline I don't know & $11(20 \%)$ \\
\hline \multicolumn{2}{|c|}{ Do you perform periodic maintenance on your $x$-ray equipment every 2 years? } \\
\hline Yes, I do it every 2 years & $17(30.9 \%)$ \\
\hline Within less than 2 years & $11(20 \%)$ \\
\hline At intervals of more than 2 years & $11(20 \%)$ \\
\hline When I think it is necessary & $16(29 \%)$ \\
\hline
\end{tabular}

Source: Authors (2019).

When the dentists were questioned about the technical details of the equipment (Table 1), the X-ray equipment tube voltage $(\mathrm{kVp})$ obtained the highest response rate, with most of the professionals $(74.5 \%)$ stating that they did not know how to define the voltage of their intraoral radiography equipment; $92.7 \%$ reported using the circular collimator and $89.1 \%$ reported that the trigger cable of the X-ray equipment measured at least 2 meters.

In Brazil (Terini \& Herdade, 2009; Vivolo et al., 2012; Pires, 2007), and in other countries (Baorong et al., 2000; Ramirez et al., 2004; Hourdakis, 2011), several studies have been carried out on the tension applied in the X-ray tube, although for a long time there was no agreement among manufacturers, physicists, engineers and service personnel in general about the most appropriate definition of tension to be used as reference. According to Hourdakis (2011), besides the nominal voltage which is the voltage value selected on the equipment panel, some of the existing definitions are: Average Voltage $\left(\mathrm{U}^{-}\right)$, Average Peak Voltage (kVp), Maximum Peak Voltage (Up), and Practical Peak Voltage (PPV). 
In order to define a precise quantity for voltage comparisons related to the final effect on the X-ray image, the Practical Peak Voltage (PPV) was proposed by Kramer and adopted as the standard quantity for X-ray tube voltage in diagnostic radiology (Kramer et al., 1998). Today, some manufacturers (Gammex, RadCal, RTI and PTW) of non-invasive Xray tube voltage meters have adopted the PPVas one of the standard quantities measured by their instruments (Hourdakis, 2011). In addition, the IEC 61676 standard indicates the requirements for the evaluation of the performance of noninvasive $X$ ray tube voltage meters and defines the PPV as the standard magnitude (IEC, 2002).

The ojective of the questions about the conduct and protocols adopted by the professionals in clinical practice was to promote the lowest possible radiation exposure both for the patient and the operator, as shown in Table 2; 56.4\% reported the use of higher radiation doses, while only $3.6 \%$ opted for the lowest dose for radiographic examinations. The paralleling technique was used by most of the participants $(81.8 \%)$. Most respondents $(56.4 \%)$ stated that they placed the localizer cylinder as close as possible to the skin of the patient, while $23.6 \%$ placed it as far away as possible and $3.6 \%$ stated that the distance of the skin cylinder was not relevant. The position-distance rule at the time of the examination is respected by most participants (50.9\% using a distance of $2 \mathrm{~m}$ and $41.8 \%$ a distance of $>2 \mathrm{~m}$ from the cylinder); $98.2 \%$ use patient protection barriers, although $25.5 \%$ reported not using the barriers in all the radiographic examinations they perform. Both Administrative Rule 453/98 and RDC-330-19 recommend the lowest possible exposure.

According to Okuno and Yoshimura (2010) and Okuno (2018), ionizing radiation has biological implications when we are exposed to doses above the pre-established limits for radioprotection, that may contribute to stochastic effects such as cancer. In addition to suffering a stochastic effect, our body responds to ionizing radiation in several ways, with effects on organs or tissues due to ion formation and with genetic factors such as inherent defects in DNA metabolism or repair. The biological effect of ionizing radiation results in the formation of free radicals that can cause damage to DNA, considered a molecule of great importance, and cell death, carcinogenesis or mutation (Yoshimura, 2010; Lara, 2016; Okuno, 2018). Thus, one way to ensure that individuals are exposed as little as possible is to keep the patient at the minimum distance recommended by the health agency during imaging examinations so that the dose equivalent is lower than that defined for the free area determined by the radiometric survey. The results of the exposure time spent by dental surgeons during intraoral radiography examinations are presented in Table 2.

Table 2. Working procedures.

\begin{tabular}{lc}
\hline Questions & Answers \\
\hline What exposure time do you normally use for intraoral radiographs? & $2(3.6 \%)$ \\
\hline$<0.2$ & $3(5.5 \%)$ \\
$\mathbf{0 . 2 - 0 . 3}$ & $8(14.5 \%)$ \\
$\mathbf{0 . 3 - 0 . 4}$ & $31(56.4 \%)$ \\
$\mathbf{0 . 4 - 0 . 8}$ & $9(16.4 \%)$ \\
$>\mathbf{0 . 8}$ & $2(3.6 \%)$ \\
I don't know &
\end{tabular}

Which technique do you use the most:

Bisector

How far do you position the locator cylinder in relation to the skin? 
As close as possible

Whatever, it's not relevant

The positioner distance

What type of image receiver do you use?

Conventional film

Photostimulable phosphor plate (PSP)

Coupled charge device (CCD)

Metal oxide semi-conductor (CMOS)

What type of radiographic/digital processing do you use?

\begin{tabular}{lc}
\hline Manual & $53(96.4 \%)$ \\
Automatic & $0(0 \%)$ \\
Digital & $9(16.4 \%)$ \\
\hline If manual, do you follow the manufacturer's instructions for changing solutions? & $46(83.6 \%)$ \\
\hline Yes & $9(16.4 \%)$ \\
\hline
\end{tabular}

Do you use a light box to evaluate your radiographs?

\begin{tabular}{lc}
\hline Yes & $45(85.5 \%)$ \\
No & $8(14.5 \%)$ \\
\hline How far away from the cylinder do you stand at the time of the examination (position-distance rule)? & $1(1.8 \%)$ \\
\hline$\leq \mathbf{1 m}$ & $28(50.9 \%)$ \\
$\mathbf{2 m}$ & $23(41.8 \%)$ \\
$>\mathbf{2 m}$ & $3(5.5 \%)$ \\
\hline I don't know &
\end{tabular}

Do you have radiation protection barriers?

\begin{tabular}{lr}
\hline Yes & $54(98.2 \%)$ \\
No & $1(1.8 \%)$
\end{tabular}

What protective barriers do you offer the patient during exposure?

\begin{tabular}{lc}
\hline Thyroid collar & $0(0 \%)$ \\
Lead apron & $10(18.2 \%)$ \\
Lead apron + thyroid collar & $45(81.8 \%)$ \\
\hline Do you use these barriers in all radiographic exams you perform? & $41(74.5 \%)$ \\
\hline Yes & $14(25.5 \%)$ \\
No & $47(85.5 \%)$ \\
\hline $\begin{array}{l}\text { If other individuals are required to assist the patient during the examination, do you advise them not to } \\
\text { stand in the direction of the primary beam and to use a lead apron? }\end{array}$ & $8(14.5 \%)$ \\
\hline Yes & \\
\hline No & \\
\hline
\end{tabular}


Regarding the use of conventional films, Administrative Rule 453/98 ${ }^{1}$ issued a series of recommendations for the use of films in offices, such as: (a) Follow the manufacturer's recommendations as to solution concentration, time and temperature in order to ensure adequate radiographic processing; (b) Monitor the solutions regularly and recover them, when necessary, taking into account the quantity of films processed; (c) Carry out periodic preventive maintenance in automatic processors; (d) Keep the darkroom clean and ensure its exclusive use for its intended purpose, and (e) Routinely monitor the temperature and humidity of the darkroom [... ].

RDC 330/19 (2019), a resolution that replaces 453/98, prohibits the use of conventional films but makes an exception for the practice of manual processing of radiographic films regarding intraoral dental radiology or in temporary conditions of urgent or emergency care, upon the opinion of the responsible technician (RDC, 330/19, p. 16).

$\S 1$ In intraoral dental radiology, portable manual development cameras made of opaque material may be used, and the service must have a chronometer, thermometer, development table and other resources to ensure processing according to manufacturers' instructions for use (RDC, 330/19, p. 16).

$\S 2$ In all other cases, the darkroom for manual development should be fitted with a chronometer, thermometer, development table and other resources to ensure processing in accordance with the manufacturers' instructions for use (RDC, $330 / 19$, p. 16).

Art. 83 The system to control the duration of exposure to X-rays shall be electronic and shall not allow exposure lasting longer than 5 (five) seconds, except in fluoroscopy, interventional radiology, computed tomography and extraoral dental radiology (RDC, 330/19, p. 16).

The survey revealed that most dentists $(96.4 \%)$ use conventional film, while the photostimulable phosphor plate (PSP) and the charge-coupled device (CCD) are less used (10.9\% and 5.5\%, respectively). As shown in Figure 2, 54.5\% of the respondents do not know the sensitivity of the film they use and $6.4 \%$ process their radiographs manually. Processing solutions are also essential to ensure image quality; $83.6 \%$ of the respondents follow the manufacturer's instructions when changing solutions, but $87.2 \%$ do not measure the temperature of the developer before processing. In this respect, there is a need for constant updating on the part of dental surgeons, requiring a constant analysis of the current ordinances and resolutions, so that they can be more efficient in the daily practice of dentistry in order to minimize the adverse effects that may arise during imaging examinations in intraoral dental radiology.

Figure 2. Film sensitivity.

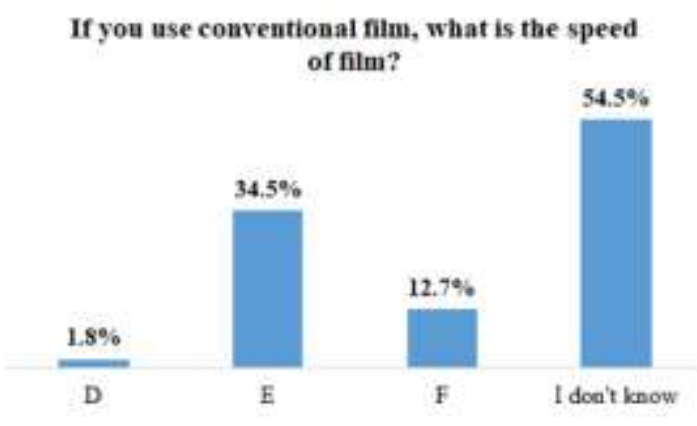

Source: Authors (2019).

${ }^{1}$ Federal Ordinance No. 453 of 1 June 1998. <https://www.saude.go.gov.br/images/imagens_migradas/upload/arquivos/2013-08/portaria453-radiodiagnostico.pdf.> 
Regarding quality control, the study showed that the average age of the most frequently used X-ray equipment was $<5$ years $(30.9 \%)$, followed by equipment $>10$ years old $(27.3 \%)$. Periodic maintenance every 2 years was reported by $30.9 \%$ of the professionals; however, about $29 \%$ mentioned that they perform the quality control of their X-ray equipment only when they find it necessary (Table 1).

However, as of December 20, 2019, the Collegiate Board of the National Health Surveillance Agency revoked Ordinance SVS/MS No. 453, of June 1, 1998 and Resolution Anvisa/RE No. 1016, of April 3, 2006, and established a period of 12 months for adaptation after publication of new regulations (RDC 330/19). Thus, quality control now involves new rules for facilities and new equipment, and the inclusion of new diagnostic or interventional radiology equipment must be approved by the competent health authority before changes are made. Also, modifications of any parameter used for the shielding projects of the service must be communicated to the competent health authority prior to their effectuation. (RDC, 330/2019, p. 5). Regarding the maximum annual radiation dose for the public, the dental surgeons were asked about the average number of imaging examinations (intraoral, panoramic, cephalometric and cone beam computed tomography) needed to reach the maximum annual radiation dose of $1 \mathrm{mSv}$, to which the public may be exposed. Table 3 lists the number of radiographs (intraoral, panoramic and cephalometric) reported by the respondents to reach the radiation dose of $1 \mathrm{mSv}$. For the intraoral exams, the number of radiographs with the highest percentage of choice by the professionals was 10-20 radiographs (32.7\%) and the alternative that came closest to the correct number, 60-80 intraoral radiographs, was chosen by only $5.4 \%$. Regarding panoramic examinations, $29.1 \%$ stated that $10-20$ radiographs would be necessary to achieve $1 \mathrm{mSv}$, while only $11 \%$ chose the closest option, 40-60. Finally, regarding cephalometric radiographs, 43.7\% indicated that the answer would be $<50$ examinations, while only $1.8 \%$ indicated the value closest to the correct one, i.e.,> 200 cephalometric. The maximum dose of radiation exposure was specified in Ordinance 453/981 (1998), whereas RDC.330/19² (2019) required that the normal occupational exposure of each individual, arising from all their practices should be controlled The Commission shall inform the Member States of the dose limits laid down by the National Nuclear Energy Commission ${ }^{3}$.

${ }^{2}$ Resolution - RDC N ${ }^{o} 330$, of 20 december 2019. < https://www.in.gov.br/web/dou/-/resolucao-rdc-n-330-de-20-de-dezembro-de-2019235414748? inheritRedirect=true>

${ }^{3}$ National Commission of Nuclear Energy - CNE. https://www.gov.br/cnen/pt-br/search?SearchableText=radia\%C3\%A7\%C3\%A3o 
Table 3. Maximum annual radiation dose for the public (X-rays and CT scans).

\begin{tabular}{|c|c|}
\hline $\begin{array}{l}\text { On average, how many radiographs are equivalent to the maximum annual radiation } \\
\text { dose recommended by Ordinance } 453 / 98 \text { ? }\end{array}$ & Answers \\
\hline \multicolumn{2}{|l|}{ Intraoral } \\
\hline$<10$ & $9(16.3 \%)$ \\
\hline $10-20$ & $18(32.7 \%)$ \\
\hline $20-40$ & $15(27.2 \%)$ \\
\hline $40-60$ & $2(3.6 \%)$ \\
\hline $60-80$ & $3(5.4 \%)$ \\
\hline I don't know & $4(7.2 \%)$ \\
\hline \multicolumn{2}{|l|}{ Panoramic } \\
\hline$<10$ & $17(31 \%)$ \\
\hline $10-20$ & $16(29.1 \%)$ \\
\hline $20-40$ & $9(16.3 \%)$ \\
\hline $40-60$ & $6(11 \%)$ \\
\hline$>60$ & $1(1.8 \%)$ \\
\hline I don't know & $6(10.9 \%)$ \\
\hline \multicolumn{2}{|l|}{ Cephalometric } \\
\hline$<\mathbf{5 0}$ & $24(43.7 \%)$ \\
\hline $50-100$ & $13(23.7 \%)$ \\
\hline $100-150$ & $5(9.1 \%)$ \\
\hline $150-200$ & $4(7.3 \%)$ \\
\hline$>200$ & $1(1.8 \%)$ \\
\hline $\begin{array}{l}\text { On average, how many CT scans are equivalent to the maximum annual radiation } \\
\text { dose recommended by Ordinance } 453 / 98 ?\end{array}$ & Answers \\
\hline \multicolumn{2}{|l|}{ Small FOV } \\
\hline 1 & $9(16.4 \%)$ \\
\hline 2 & $8(14.5 \%)$ \\
\hline 3 & $12(21.8 \%)$ \\
\hline 4 & $7(12.7 \%)$ \\
\hline$>5$ & $11(20 \%)$ \\
\hline I don't know & $8(14.5 \%)$ \\
\hline \multicolumn{2}{|l|}{ Medium FOV } \\
\hline 1 & $8(14.5 \%)$ \\
\hline 2 & $10(18.1 \%)$ \\
\hline 3 & $16(29.1 \%)$ \\
\hline 4 & $6(10.9 \%)$ \\
\hline$>5$ & $6(10.9 \%)$ \\
\hline
\end{tabular}




\begin{tabular}{ll} 
I don't know & $9(16.3 \%)$ \\
\hline Large FOV & \\
\hline $\mathbf{1}$ & $15(27.3 \%)$ \\
$\mathbf{2}$ & $14(25.5 \%)$ \\
$\mathbf{3}$ & $7(12.7 \%)$ \\
$\mathbf{4}$ & $4(7.3 \%)$ \\
$>\mathbf{5}$ & $6(10.9 \%)$ \\
$\mathbf{I}$ don't know & $9(16.3 \%)$ \\
\hline
\end{tabular}

Source: Authors (2019).

Figure 3 illustrates the percentage of respondents who chose the alternatives with the most similar number of radiographs required to achieve the maximum annual radiation dose for the public. Table 3 also shows the number of cone beam CT examinations in the 3 field of view (FOV) sizes needed to approach $1 \mathrm{mSv}$. The alternatives considered closest to correct were 3 small FOV examinations, 2 medium FOV examinations, and 2 large FOV examinations. The results obtained showed that only $21.8 \%$ of the respondents opted for 3 small FOV scans, $18.1 \%$ opted for 2 medium FOV scans and $25.5 \%$ opted for 1 large FOV scan, which would be the correct values needed to achieve the maximum annual radiation dose (Figure $3)$.

Figure 3. Number of X-rays and CT scans needed to achieve the maximum annual radiation dose for the audience of $1 \mathrm{mSv}$ ) (percentage of hits).
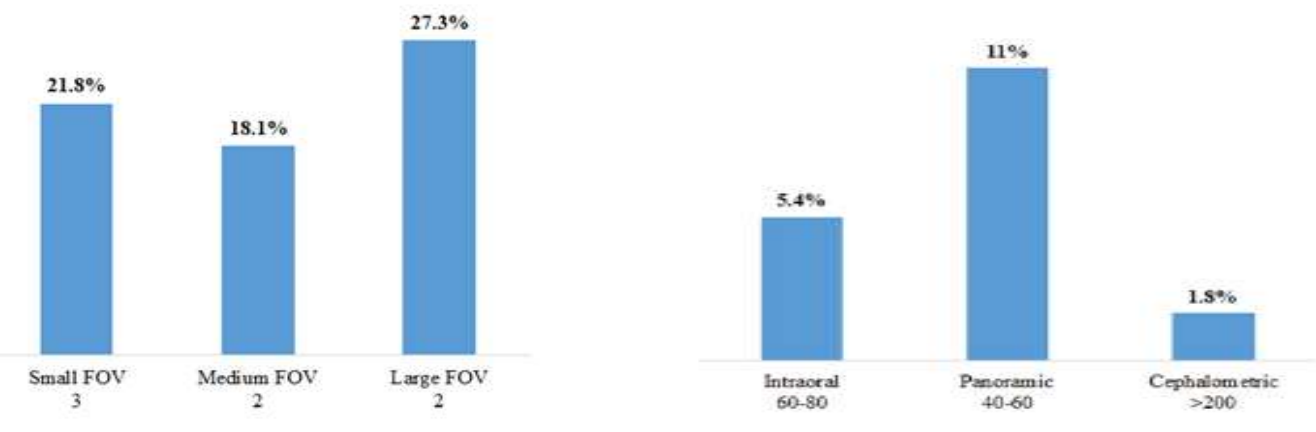

Source: Authors (2019).

The principle of periapical, interproximal, panoramic, cephalometric or even cone beam computed tomography imaging exams, advocates exposing the patient to the lowest possible radiation dose, provided that it is feasible to reach a diagnosis with the acquired image. However, this and other studies show that the conduct of professionals is not so faithful to this principle (Ihle et al., 2019; Shahab et al., 2012; Chaudhry et al., 2016; Sheikh et al., 2014; Ilgüy et al., 2005).

Given the above, every professional who performs imaging examinations, should know and put into practice three basic principles that contribute to minimal radiation exposure at the time of examinations, i.e., time, distance and shielding in all operations (Okuno,2018). This is the central basis of radiological safety since it deals with the propagation of energy which may contain radioactive elements. In addition, protective equipment, dosimetry and supervision are considered essential.

The present study indicates that $64 \%$ of the participants were unaware of the rules contained in Resolution $453 / 98$ in force until December 2019, and 49.1\% were unaware of the principles of radioprotection. In the present study, only $9.1 \%$ of 
the respondents did not consider the thyroid to be the most important organ for radiological protection, as opposed to about $35 \%$ of the respondents in other studies. The incorrect answers were that bone marrow, skin and sex gonads are the most essential organs for protection (Ihle et al., 2019; Shahab et al., 2012; Chaudhry et al., 2016).

Regarding the comparison between the radiation dose of a panoramic versus a whole mouth periapical examination, the results were similar to those reported in the literature (Ihle et al., 2019; Shahab et al., 2012; Chaudhry et al., 2016). Previous studies have reported that $30 \%$ of the participants erroneously stated that panoramic radiography involves the highest radiation dose, a result similar to that obtained in the present study (29.1\%). The exposure duration control system should permit the interruption of exposure at any time.

The requirements established by ordinance 453/98 and the RDC 330/192 regarding the installations, the utilization of a thermometer, chronometer and time-temperature table during processing are of fundamental importance to ensure the quality of the acquired image and to avoid repetition of the images. Regarding the use of such equipment, $83.6 \%$ of the dental surgeons reported not having any of these components available, in addition to the fact that $87 \%$ did not measure the temperature of the developer before processing, indicating a lack of guarantee and quality control of the examination. Similar data have also been reported in another study (74\% and 87\%, respectively) (Mutyabule \& Whaites, 2002).

Knowledge of the professionals about the equipment, particularly the tube voltage of the X-ray equipment, proved to be insufficient. The use of diagnostic or interventional radiology is based on equipment with a tube powered by a self-rectified high voltage generator or with half wave rectification, except for intraoral dental radiology equipment. Among the respondents, $74.5 \%$ reported not knowing the tube voltage of their equipment $(\mathrm{kVp})$, a result similar to that obtained in another study in which $82 \%$ of the participants were also unaware (Sheikh et al., 2014).

Regarding the collimation used, the size and shape of the X-ray beam are determining factors for the dose to which the patient will be exposed. According to the literature, the reduction of the exposure dose varies from $40 \%$ to $60 \%$, and despite the great potential to restrict the X-ray beam, in no case was the rectangular collimator used (Ihle et al., 2019; Shahab et al., 2012; An SY, 2018; Chaudhry et al., 2016; Sheikh et al., 2014; Ilgüy et al., 2005; Shetty et al., 2019).

This result is equivalent to that reported in other studies that also found a very limited use of this collimation (Shahab et al., 2012; Chaudhry et al., 2016; Aps, 2010; Ilgüy et al., 2005). The fact that rectangular cones need to be purchased and installed separately can be seen as an unnecessary hassle, explaining their low use by practitioners (Ihle et al., 2019).

In view of all the aspects related to the environment and equipment, the process of optimizing protection in work procedures should be emphasized since it directly influences the quality and safety of patient care. The marked vertical angulation in the bisector technique results in much higher chances of radiation exposure of the thyroid gland and the lens. Therefore, the paralleling technique should be preferred by practitioners since, besides producing more accurate images, it involves less radiation exposure. Fortunately, in the present study, $81.8 \%$ of the respondnets reported using the paralleling technique, in contrast to several other authors who found a preference for the bisector technique (Shahab et al., 2012; Chaudhry et al., 2016; Sheikh et al. al., 2014; Ilgüy et al., 2005). According to the type of intraoral receiver, high quality images can be produced with a relatively lower radiation dose, as is the case with the digital sensor.

Thus, patient safety is the responsibility of the healthcare professional performing periapical, interproximal, panoramic, cephalometric or even cone beam computed tomography imaging examinations, in order to avoid risks and/or accidents. Professionals should be aware of safety issues and, especially, report all adverse events, so that they can be analyzed and documented to avoid future accidents. 


\section{Final Considerations}

The ojective of the present study was to identify the knowledge of dental surgeons about Ordinance SVS/MS No. 453 dated June 1st 1998, which approved the Technical Regulation and established the basic guidelines for radiological protection in medical and dental radiodiagnosis dealing with the use of X-rays [... $]^{4}$. The present study has revealed a lack of knowledge on the part of dental surgeons about the rules and guidelines for the practice of radiology and radioprotection, emphasizing the need for dental surgeons to improve their knowledge.

Further studies are needed as well as greater awareness on the part of dental surgeons about ways of minimizing patient exposure during imaging procedures. This would raise the interest in social sustainability on the part of the dental class, with the formation of a collective consciousness about the excessive or unnecessary exposure of the patients they care for. There is also a need for better training in graduation and post-graduation since all knowledge and training directly influence the conduct adopted by the dental surgeon. Regardless of the update of ordinances and resolutions, updated knowledge is necessary, so that we may overcome the barrier of lack of significant knowledge.

\section{Acknowledgments}

This work was carried out with support from the Coordination of Improvement of Higher Education Personnel Brazil (CAPES) - Funding Code 001.

\section{References}

Alcaraz, M., Parra, C., Martínez Beneyto, Y., Velasco, E., \& Canteras, M. (2009). Is it true that the radiation dose to which patients are exposed has decreased with modern radiographic films? Dento maxillo facial radiology, 38(2), 92-97. https://doi.org/10.1259/dmfr/78589833

Almohaimede, A. A., Bendahmash, M. W., Dhafr, F. M., Awwad, A. F., \& Al-Madi, E. M. (2020). Knowledge, Attitude, and Practice (KAP) of Radiographic Protection by Dental Undergraduate and Endodontic Postgraduate Students, General Practitioners, and Endodontists. International journal of dentistry, 2020, 2728949. https://doi.org/10.1155/2020/2728949

An, S. Y., Lee, K. M., \& Lee, J. S. (2018). Korean dentists' perceptions and attitudes regarding radiation safety and protection. Dento maxillo facial radiology, 47(3), 20170228. https://doi.org/10.1259/dmfr.20170228

Aps J. K. (2010). Flemish general dental practitioners' knowledge of dental radiology. Dento maxillo facial radiology, 39(2), 113-118. https://doi.org/10.1259/dmfr/52763613

Baorong, Y., Kramer, H. M., Selbach, H. J., \& Lange, B. (2000). Experimental determination of practical peak strain. The British Journal of radiology, 73 (870), 641-649.

BRAZIL. Resolution - RDC No. 330, of December 20, 2019. Diário Oficial da União, Brasília, 26 December 2019.

Binnal, A., Rajesh, G., Denny, C., Ahmed, J., \& Nayak, V. (2013). Insights into the state of radiation protection among a subpopulation of Indian dental practitioners. Imaging science in dentistry, 43(4), 253-259. https://doi.org/10.5624/isd.2013.43.4.253

Chaudhry, M., Jayaprakash, K., Shivalingesh, K. K., Agarwal, V., Gupta, B., Anand, R., Sharma, A., \& Kushwaha, S. (2016). Oral Radiology Safety Standards Adopted by the General Dentists Practicing in National Capital Region (NCR). Journal of clinical and diagnostic research: JCDR, 10(1), ZC42ZC45. https://doi.org/10.7860/JCDR/2016/14591.7088

Chauhan, V., \& Wilkins, R. C. (2019). A comprehensive review of the literature on the biological effects from dental X-ray exposures. International journal of radiation biology, 95(2), 107-119. https://doi.org/10.1080/09553002.2019.1547436

De Souza Pereira, W., Kelecom, A., \& de Souza Pereira, J. R. (2015). Comparison between the Brazilian radioprotection standard and the recommendation of the International Commission on Radiological Protection published in 2007. Brazilian Journal of Radiation Sciences, 3(2).

Furmaniak, K. Z., Kołodziejska, M. A., \& Szopiński, K. T. (2016). Radiation awareness among dentists, radiographers and students. Dento maxillo facial radiology, 45(8), 20160097. https://doi.org/10.1259/dmfr.20160097

Hourdakis, C. J. (2011). Determination of the diagnostic x-ray tube practical peak voltage (PPV) from average or average peak voltage measurements. Physics

${ }^{4}$ This research aimed to seek and identify what was the knowledge of dental surgeons regarding the Ordinance SVS/MS No 453 of June 1, 1998, which approved the Technical Regulation that established the basic guidelines for radiological protection in medical and dental radiodiagnosis, providing on the use of x-rays [...]. However, in the course of the research the ordinance 453/98, was repealed and replaced by Resolution - RDC No. 330 , of December 20, 2019. Moreover, the RDC does not mention the professions as the ordinance 453/98 did (in breach of the FC) and now employs the terminology more adjusted to the legally qualified professional (BRASIL,2019). 
in Medicine \& Biology, 56(7), 2199.

Ihle, I. R., Neibling, E., Albrecht, K., Treston, H., \& Sholapurkar, A. (2019). Investigation of radiation- protection knowledge, attitudes, and practices of North Queensland dentists. Journal of investigative and clinical dentistry, 10(1), e12374.

Ilgüy, D., Ilgüy, M., Dinçer, S., \& Bayirli, G. (2005). Survey of dental radiological practice in Turkey. Dento maxillo facial radiology, 34(4), 222-227. https://doi.org/10.1259/dmfr/22885703

Kramer, H. M., Selbach, H. J., \& Iles, W. J. (1998). The practical peak voltage of diagnostic X-ray generators. The British journal of radiology, 71(842), 200209.

Lara, M. Q. Riscos radiobiológicos das tomografias computadorizadas de feixe cônico: uma revisão sistemática. 2016, 55f. Dissertation (Master's Degree in Dentistry) - Pontifical Catholic University of Minas Gerais, Belo Horizonte, 2016.

Lavanya, R., Babu, D. B., Waghray, S., Chaitanya, N. C., Mamatha, B., \& Nithika, M. (2016). A Questionnaire Cross-Sectional Study on Application of CBCT in Dental Postgraduate Students. Polish journal of radiology, 81, 181-189. https://doi.org/10.12659/PJR.895688

Memon, A., Godward, S., Williams, D., Siddique, I., \& Al-Saleh, K. (2010). Dental x-rays and the risk of thyroid cancer: a case-control study. Acta oncologica (Stockholm, Sweden), 49(4), 447-453. https://doi.org/10.3109/02841861003705778

Mota, I. B. de O., Langoni, A. C., Almeida, G. C. T. A., Botelho, E. S., França, M. M. C., Reis, T. A., Dietrich, L., \& Nascimento, F. (2020). Análise do conhecimento na interpretação de imagens radiográficas de alunos de um curso de Odontologia. Research, Society and Development, 9(11), e88691110676. https://doi.org/10.33448/rsd-v9i11.10676

Mutyabule, T. K., \& Whaites, E. J. (2002). Survey of radiography and radiation protection in general dental practice in Uganda. Dento maxillo facial radiology, 31(3), 164-169. https://doi.org/10.1038/sj/dmfr/4600685

National agency for sanitary surveillance. Resolution-RDC N³30, of 20 december 2019. Diário Oficial da União, Brasília, DF, 20 December.2019.

Okuno, E., \& Yoshimura, E. M. (2016). Physics of radiation. Texts Workshop.

Okuno, E. (2018). Radiation: effects, risks and benefits. Text Workshop.

Perini, AP, Neves, LP, Vivolo, V., Xavier, M., Khoury, HJ, \& Caldas, LV (2012). Characterization of a CT ionization chamber for radiation field mapping. Applied Radiation and Isotopes, 70 (7), 1300-1303.

Pires, JDSJ (2007). Avaliação da grandeza tensão de pico prática em equipamentos usados em radiodiagnóstico (dissertação de doutorado, universidade de São Paulo).

Ramirez-J. F. J., Lopez-Callejas, R., Benitez-Read, J. S., \& Pacheco-Sotelo, J. O. (2004). Considerations on the measurement of practical peak voltage in diagnostic radiology. The British journal of radiology, 77(921), 745-750.

Shahab, S., Kavosi, A., Nazarinia, H., Mehralizadeh, S., Mohammadpour, M., \& Emami, M. (2012). Compliance of Iranian dentists with safety standards of oral radiology. Dentomaxillofacial Radiology, 41(2), 159-164.

Sheikh, S., Pallagatti, S., Singla, I., Gupta, R., Aggarwal, A., Singh, R., \& Gupta, D. (2014). Survey of dental radiographical practice in states of Punjab and Haryana in India. Journal of investigative and clinical dentistry, 5(1), 72-77. https://doi.org/10.1111/jicd.12016

Shetty, A., Almeida, F. T., Ganatra, S., Senior, A., \& Pacheco-Pereira, C. (2019). Evidence on radiation dose reduction using rectangular collimation: a systematic review. International dental journal, 69(2), 84-97. https://doi.org/10.1111/idj.12411

Singh, G., Sood, A., Kaur, A., \& Gupta, D. (2018). Pathogenesis, Clinical Features, Diagnosis, and Management of Radiation Hazards in Dentistry. The open dentistry journal, 12, 742-752. https://doi.org/10.2174/1745017901814010742

Tsapaki V. (2017). Radiation protection in dental radiology - Recent advances and future directions. Physica medica: PM: an international journal devoted to the applications of physics to medicine and biology: official journal of the Italian Association of Biomedical Physics (AIFB), 44, $222-226$. https://doi.org/10.1016/j.ejmp.2017.07.018

Terini, R. A, Potiens, M. D. P. A., Herdade, S. B., Pereira, M. A. G., Pires, J. D. S. J., \& Videira, H. S. (2009). A cumprir da grandeza tensão de pico prático na prática radiológica. Radiologia Brasileira, 42, 389-394.

Villalobos, M. I. de O. e B.., Martorano, J. de F., Juhás, R., \& Nakao, E. (2021). Protocolo recomendado para solicitação de exames de imagem odontológica. Research, Society and Development, 10 (7), e33210716573. https://doi.org/10.33448/rsd-v10i7.16573

White S. C., Pharoah, M. J. (2009). Oral radiology principles and interpretation (6th edn). Mosby 